\title{
Retention of total carotenoid and $\beta$-carotene in yellow sweet cassava (Manihot esculenta Crantz) after domestic cooking
}

Lucia M. J. Carvalho'*, Alcides R. G. Oliveira', Ronoel L. O. Godoy ${ }^{2}$, Sidney Pacheco², Marília R. Nutti', José L. V. de Carvalho ${ }^{2}$, Elenilda J. Pereira' and Wânia G. Fukuda ${ }^{3}$

'Pharmacy College, Universidade Federal do Rio de Janeiro, Ilha do Fundão, Rio de Janeiro, Brazil; ${ }^{2}$ Embrapa Food Technology, Rio de Janeiro, Brazil; ${ }^{3}$ Embrapa Cassava and Tropical Fruits, Cruz das Almas, Bahia, Brazil

Abstract

Background: Over the last decade, considerable efforts have been made to identify cassava cultivars to improve the vitamin A nutritional status of undernourished populations, especially in northeast Brazil, where cassava is one of the principal and essentially only nutritional source.

Objectives: The aim of this study was to evaluate the total carotenoid, $\beta$-carotene, and its all-E-, 9-, and 13-Z$\beta$-carotene isomers content in seven yellow sweet cassava roots and their retention after three boiling cooking methods.

Design: The total carotenoid, $\beta$-carotene, and its all-E-, 9-, and 13-Z- $\beta$-carotene isomers in yellow sweet cassava samples were determined by ultraviolet/visible spectrometry and high-performance liquid chromatography, respectively, before and after applying the cooking methods. All analyses were performed in triplicate. Results: The total carotenoid in raw roots varied from 2.64 to $14.15 \mu \mathrm{g} / \mathrm{g}$ and total $\beta$-carotene from 1.99 to $10.32 \mu \mathrm{g} / \mathrm{g}$. The $\beta$-carotene predominated in all the roots. The Híbrido 20031408 cultivar presented the highest $\beta$-carotene content after cooking methods 1 and 3. The 1153 - Klainasik cultivar presented the highest $9-Z$ - $\beta$-carotene content after cooking by method 3 . The highest total carotenoid retention was observed in cultivar 1456 - Vermelhinha and that of $\beta$-carotene for the Híbrido 20031411 cultivar, both after cooking method 1. Evaluating the real retention percentage $(\mathrm{RR} \%)$ in sweet yellow cassava after home cooking methods showed differences that can be attributed to the total initial carotenoid contents. However, no cooking method uniformly provided a higher total carotenoid or $\beta$-carotene retention in all the cultivars. Conclusion: Differences were found in the cooking methods among the samples regarding total carotenoid or $\beta$-carotene retention, suggesting that the different behaviors of the cultivars need to be further analyzed. However, high percentages of total carotenoid or $\beta$-carotene retention were observed and can minimize vitamin A deficiency in low-income populations.

Keywords: sweet yellow cassava; carotenoid retention; $\beta$-carotene; home cooking methods

Received: 13 December 2012; Revised: 9 February 2012; Accepted: 13 February 2012; Published: 26 March 2012

$\mathrm{V}$ itamin A deficiency (VAD) is a widespread nutritional disorder in low-income countries and is still a public health concern worldwide. The insufficient intake over a long period of time causes xerophthalmia that may lead to irreversible blindness. Furthermore, subclinical deficiency can aggravate diseases such as diarrhea and other infectious processes (1).
Provitamin A carotenoids are mainly found in plants, algae, and microorganisms and can be metabolized into vitamin $\mathrm{A}$ in humans and animals. Among the carotenoids, $\beta$-carotene and $\alpha$-carotene have a high provitamin A activity. However, heat treatment can promote $\beta$ - and $\alpha$ carotene isomerization, increasing the concentration of $\mathrm{Z}$ isomers with low provitamin A activity, mainly the 13-Z$\beta$-carotene. 
Aside from the provitamin A activity of carotenoids, they have also been credited with other health-promoting effects: immune enhancement and a reduced risk of developing degenerative diseases, such as cancer, cardiovascular diseases, cataract, and macular degeneration (2).

Over the last decade, considerable efforts have been made to identify cassava (Manihot esculenta Crantz) cultivars to improve the vitamin A nutritional status of undernourished populations in the tropics, especially in northeast Brazil, where cassava is one of the principal and almost the only nutritional source. Apart from being a rich source of carbohydrates, the sweet yellow cassava is an excellent source of carotenoids $(3,4)$. In earlier studies, over $90 \%$ of the total carotenoids present in sweet yellow cassava were $\beta$-carotene $(3,5)$.

Identifying cassava roots of good cooking quality is an important parameter in selecting cultivars for consumption; other factors that must be taken into consideration are hydrocyanic acid content, starch, fiber, cooking time, flavor, consistency, and cooked pulp texture (6).

Cooking time varies even among the same cultivar roots depending on the soil type, planting season, and plant age. Good quality cassava cooking time must be shorter than 30 min so that the pulp is easily mashed with a fork (6).

The cooking methods change the initial cassava root texture, promoting tissue hydration and starch gelatinization. Cassava water absorption varies with the cooking temperature - water at $100^{\circ} \mathrm{C}$ cooked the roots in a shorter time than cooking at $80^{\circ} \mathrm{C}$. Thus, the faster the hydration, the shorter the cooking time, and consequently, a higher yield will be obtained in the commercialization of the precooked product (7).

The aim of the present study was to determine the total carotenoid and $\beta$-carotene contents in seven raw sweet yellow cassava cultivars as well as the all- $E$, 13-, and 9-Z$\beta$-carotene isomer content and their retention in cooked roots under home cooking conditions.

\section{Materials and methods}

\section{Plant material}

Seven root samples of the sweet yellow cassava cultivars: 1456 - Vermelhinha; 1153 - Klainasik; 1668 - Cacau amarelo; 1692 - Dendê; 1721 - Aipim cacau; Híbrido 1408 and, Híbrido 14-11, were cultivated at Embrapa Cassava and Tropical Fruits, Cruz das Almas - BA, Brazil. The harvest was performed 12 months after planting.

\section{Raw material preparation}

The roots were washed to remove dirt and dried and immersed in liquid paraffin at $50-60^{\circ} \mathrm{C}$ for $45 \mathrm{sec}$. This operation was repeated three times to form a paraffin layer.

The experiments were performed at Embrapa Food Technology, Rio de Janeiro, RJ, Brazil. The roots were received and maintained at $4^{\circ} \mathrm{C}$ for 4 weeks to guarantee the preservation of their total carotenoids, $\beta$-carotene, and its $E, 13-$, and $9-Z$ isomers contents until analysis.

\section{Cooking methods}

To evaluate the retention of total carotenoids and $\beta$-carotene in the roots after the cooking process, three experiments under home cooking conditions for $30 \mathrm{~min}$ were performed using Teflon pots (Table 1). All experiments were performed in triplicate.

\section{Sample extraction and analysis}

$\beta$-carotene standard

$\beta$-carotene was extracted from carrot (Daucus carota L.), one of the best-known sources of $\alpha$ - and $\beta$-carotene $(8-12)$. The $\beta$-carotene standard from Sigma-Aldrich was used, and a calibration curve was constructed. The data obtained were analyzed with the Empower Program.

\section{Sample preparation}

The roots were placed at room temperature for $10 \mathrm{~min}$, and the paraffin layer was removed and peeled. Then, the samples were divided in four parts through two longitudinal cuts, from one end to the other, and four sections were obtained (Fig. 1). Among these, two opposite sections were discarded, and the remaining sections were used for analysis and homogenized in a vertical mixer (Black \& Decker, model Kmvsb04t, São Paulo, Brazil) to obtain a homogenous mass (13).

\section{Carotenoid extraction}

To determine the total carotenoid, $\beta$-carotene, and its $Z$ and $E$ isomers, approximately $15 \mathrm{~g}$ of each sample, plus 3 $\mathrm{g}$ of Celite 454 (Tedia, Ohio, USA), were weighed. Successive additions of $25 \mathrm{~mL}$ of acetone were performed to obtain a paste, which was transferred to a sintered funnel $(5 \mu \mathrm{m})$ coupled to a $250-\mathrm{mL}$ Buchner flask and filtered under vacuum. This procedure was repeated three times until the sample became colorless, and the extract was transferred to a $500-\mathrm{mL}$ separation funnel containing $40 \mathrm{~mL}$ of petroleum ether. The acetone was removed through the slow addition of ultrapure water (Millipore) to prevent emulsion formation. The aqueous

Table 1. Sweet yellow cassava home cooking processes

Home cooking processes

(I) Complete immersion in water $(I: 1.5 \mathrm{w} / \mathrm{v})$ and boiling in a pot without the lid

(2) Complete immersion in water $(I: I .5 \mathrm{w} / \mathrm{v})$ and boiling in a pot with the lid on

(3) Half-immersion in water $(\mathrm{I}: \mathrm{I} \mathrm{w} / \mathrm{v})$ and boiling in a pot with the lid on

Each experiment was carried out in triplicate. 


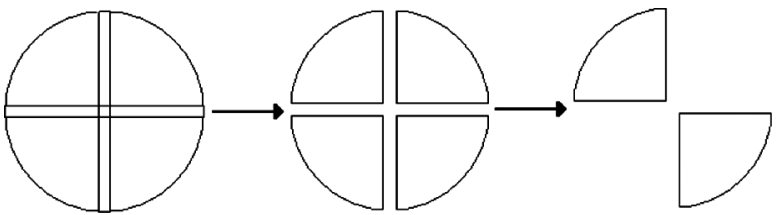

Fig. 1. Sweet yellow cassava quarterization.

phase was discarded, and this procedure was repeated four times until no residual solvent remained. The extract was then transferred through a funnel containing $15 \mathrm{~g}$ of anhydrous sodium sulfate and made up a volume of 50 $\mathrm{mL}$ with petroleum ether. The samples were read at a wavelength of $450 \mathrm{~nm}$. The total carotenoid content was calculated using the following formula:

Carotenoid contents $(\mu \mathrm{g} / \mathrm{g})=\frac{A \times V(\mathrm{~mL}) \times 10^{4}}{A_{1}^{1 \%}{ }_{\mathrm{cm}} \times P(\mathrm{~g})}$,

where $\mathrm{A}=$ absorbance, $\mathrm{V}=$ total extract volume, $\mathrm{P}=$ sample weight, and $A_{1}^{1 \%} \mathrm{~cm}=2592$ ( $\beta$-carotene extinction coefficient in petroleum ether).

Identification and quantification of $\beta$-carotene and isomers For identifying and quantifying $\beta$-carotene and its $E$ and $Z$ isomers, $2 \mathrm{~mL}$ was removed from the extract and dried in an amber flask under nitrogen flow. The sample was diluted in $100 \mu \mathrm{L}$ of acetone under shaking in a vortex mixer (Genie 2-Scientific Industries) and transferred to a 2-mL amber flask for high-performance liquid chromatography (HPLC) analyses.

The concentration of $\beta$-carotene and its $E$ and $Z$ isomers was determined using the following formula:

$C(\mu \mathrm{g} / \mathrm{g})=\frac{A_{x} \times C_{s}(\mu \mathrm{g} / \mathrm{mL}) \times V(\mathrm{~mL})}{A_{s} \times P(\mathrm{~g})}$

where $A_{x}=$ carotenoid peak area, $C_{s}=$ standard concentration, $A_{s}=$ standard area, $V=$ total extract volume, and $P=$ sample weight.

\section{Instrumental analysis}

The total carotenoids were determined using a spectrophotometer (Specord 210, model Analytikjena) at $450 \mathrm{~nm}$. The standards, $\beta$-carotene, and its isomers ( $E$ and $Z$ ) were analyzed by HPLC (Waters 2695 - Alliance Model, Milford, USA) and a UV/Visible photodiode array detector and then scanned between 350 and $600 \mathrm{~nm}$ using Empower software. A $\mathrm{C}_{30}$ column (YCM Carotenoid S-3, $4.6 \times 250 \mathrm{~mm}$, reversed-phase) was purchased from Waters. The mobile phase HPLC-grade solvents were purchased from Tedia (Rio de Janeiro, RJ, Brazil) and consisted of 8:2 methanol:t-butyl methyl ether (v:v). The mobile phase flow rate was $0.8 \mathrm{~mL} / \mathrm{min}$, and $25 \mu \mathrm{L}$ of an ether extract sample was injected. The temperature of the column was $30^{\circ} \mathrm{C}$, with a total analysis time of $60 \mathrm{~min}$.

\section{Real retention ( $R R \%)$}

The real retention $(\mathrm{RR} \%)$ in dry mass was calculated using the following formula:

$\mathrm{RR} \%=($ total carotenoid content $/ \mathrm{g}$ of cooked root

$\times$ weight $(\mathrm{g})$ of the cooked root $\times 100)$

/(total carotenoid/g of raw root

$\times$ weight $(\mathrm{g})$ of raw root)

\section{Moisture analysis}

The moisture analysis of raw and cooked cassava samples was performed using the gravimetric method, according to methodology developed by the Instituto Adolfo Lutz (14).

\section{Statistical analysis}

All data were treated by analysis of variance (ANOVA). The treatment averages were compared using the least significance difference test (LSD) at the level of 5\% of the probability. All statistical analyses were performed using Statistica software version 5.1.

\section{Results}

The $\beta$-carotene standard obtained from carrot (D. carota, L) had a purity of $93.99 \%$, as verified by the HPLC chromatogram on Fig. 2. The equation, obtained from a linear regression tendency line, generated a calibration curve equal to $Y=4.05 \times 10^{5} X+5.52 \times 10^{4}$ with a correlation coefficient of $0.9826\left(R^{2}\right)$.

The content of the $\beta$-carotene extract was $6.29 \mu \mathrm{g} / \mathrm{mL}$ and was corrected to $5.91 \mu \mathrm{g} / \mathrm{mL}$, according to the purity level.

The total carotenoid of the sweet yellow cassava cultivars ranged from 2.64 to $14.15 \mu \mathrm{g} / \mathrm{g}$ (1668 - Cacau amarelo and 1456 - Vermelhinha, respectively), and the total $\beta$-carotene varied from 1.99 to $8.11 \mu \mathrm{g} / \mathrm{g}$ (1456 - Vermelhinha and Híbrido 200314 08, respectively) (Table 2).

The median moisture content among the raw and cooked cassava samples were $69( \pm 0.15)$ and $74( \pm 0.31)$ $\mathrm{g} \cdot 100 \mathrm{~g}^{-1}$, respectively. No significant differences were found $(P<0.05)$.

The all- $E$ - $\beta$-carotene isomer was the most abundant in all the roots, ranging from 1.0 (1456 - Vermelhinha and 1668 - Cacau amarelo) to $7.27 \mu \mathrm{g} / \mathrm{g}$ (Híbrido 20031408 and Híbrido 200314 11) (Table 3 and Figs. 3 and 4).

The 13-Z- $\beta$-carotene content varied from 0.29 (1668Cacau amarelo) to $0.52 \mu \mathrm{g} / \mathrm{g}$ (1456 - Vermelhinha) and that of 9-Z- $\beta$-carotene from 0.25 (1692 - Dendê) to 1.12 $\mu \mathrm{g} / \mathrm{g}$ (1153 - Klainasik) (Table 3).

The 9-Z- $\beta$-carotene percentages were higher than those of the $13-Z$ isomer in five sweet yellow cassava cultivars, mainly cultivar 1668 - Cacau amarelo (32\%), and the lowest in cultivar 1456 - Vermelhinha (2\%). The 13- and 


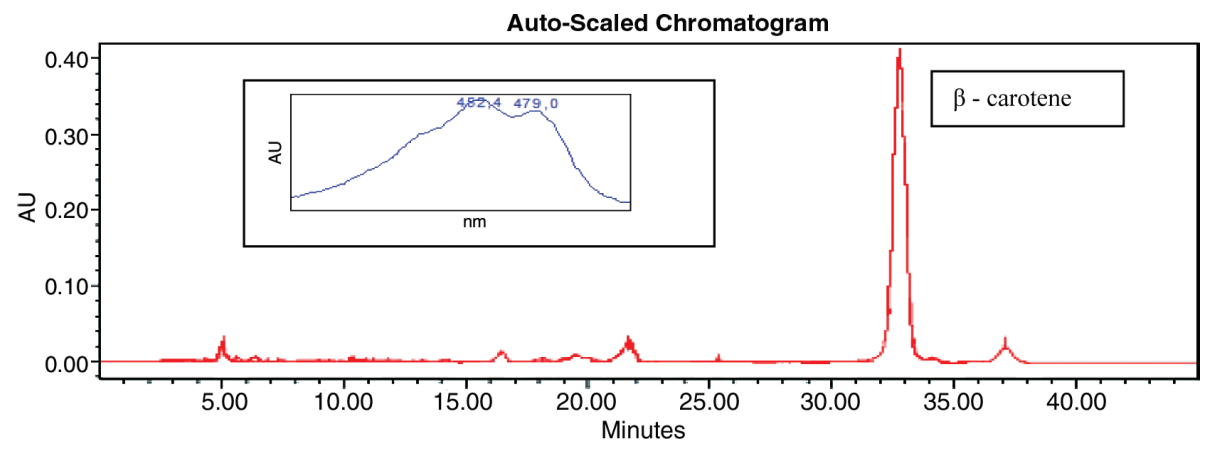

Fig. 2. Chromatogram of the $\beta$-carotene standard extracted from $D$. carota $\mathrm{L}$ determined by HPLC and $\beta$-carotene UV/visible spectrum.

9-Z- $\beta$-carotene isomers presented similar or higher contents in the raw roots of the cultivars 1668 - Cacau amarelo, 1692 - Dendê, 1721 - Aipim cacau, Híbrido 200314 08, and hybrid 20031411.

In general, there was a variation in the $\mathrm{RR} \%$ of the total carotenoids and total $\beta$-carotene among the cultivars in home cooking process 1, varying from 53.61 (1692 - Dendê) to $99.49 \%$ (1456 - Vermelhinha) and from 33.25 (1456 - Vermelhinha) to 94.31\% (Hibrido 200314 11) (Table 4).

After home cooking process 2, all the cultivars presented a total carotenoid RR $\%$ above $60 \%$, varying from $69.38 \%$ (1721 - Aipim cacau) to 92.65\% (1456 Vermelhinha), while that for $\beta$-carotene varied from $33.25 \%$ (1456 - Vermelhinha) to $88.07 \%$ (1692 - Dendê).

In home cooking process 3 , the $\mathrm{RR} \%$ of the total carotenoids varied from $62.97 \%$ (1456 - Vermelhinha and Híbrido 20031408$)$ to $82.46 \%$ (1692 - Dendê) and that of $\beta$-carotene varied from 32.06\% (1456 - Vermelhinha and Híbrido 20031408 ) to 85.79\% (1692 - Dendê).

The $E$ - $\beta$-carotene was the predominant isomer in the three home cooking methods.

Statistical analysis revealed significant differences $(\mathrm{LSD}=89.36, P<0.001)$ between the three types of

Table 2. Total carotenoids and total $\beta$-carotene contents $(\mu \mathrm{g} / \mathrm{g} \pm$ $\mathrm{SD})$ and total $\beta$-carotene (\%) in raw sweet yellow cassava

\begin{tabular}{lccc}
\hline Cassava roots & $\begin{array}{c}\text { Total } \\
\text { carotenoids }\end{array}$ & $\begin{array}{c}\text { Total } \\
\beta \text {-carotene }\end{array}$ & $\begin{array}{c}\text { Total } \\
\beta \text {-carotene (\%) }\end{array}$ \\
\hline I456 - Vermelhinha & $14.15 \pm 0.64$ & $1.99 \pm 0.09$ & 14 \\
Híbrido 2003 I4 08 & $10.32 \pm 0.94$ & $8.11 \pm 0.06$ & 78 \\
Híbrido 2003 I4 II & $7.03 \pm 0.1 I$ & $5.37 \pm 0.5$ I & 76 \\
I72I - Aipim cacau & $4.43 \pm 0.46$ & $2.84 \pm 0.35$ & 64 \\
II53 - Klainasik & $3.99 \pm 0.63$ & $3.29 \pm 0.06$ & 82 \\
I692 - Dendê & $3.19 \pm 0.04$ & $2.38 \pm 0.14$ & 75 \\
I668 - Cacau amarelo & $2.64 \pm 0.53$ & $2.11 \pm 0.02$ & 80 \\
\hline
\end{tabular}

Each analysis was carried out in triplicate. home cooking methods with the highest mean $\mathrm{RR} \%$ in total carotenoids observed in the home cooking method 2 $(81.51 \pm 12.64)$, followed by home cooking method 3 $(80.95 \pm 14.02)$ and home cooking method 1 (77.90 \pm 15.91).

Reductions were observed in the contents of 13- and 9$Z$ - $\beta$-carotene isomers after all the home cooking methods for the cultivars 1153 - Klainasik, 1456 - Vermelhinha, and 1721 - Aipim cacau.

The 13- and 9-Z- $\beta$-carotene isomers presented similar or higher contents in the raw roots of the cultivars 1668 Cacau amarelo, 1692 - Dendê, 1721 - Aipim cacau, Híbrido 200314 08, and hybrid 20031411.

The Híbrido 20031408 cultivar presented the highest content of all- $E$ - $\beta$-carotene $(4.55 \mu \mathrm{g} / \mathrm{g})$ after home cooking method 1 and the highest content of the $13-Z$ $\beta$-carotene isomer $(0.79 \mu \mathrm{g} / \mathrm{g})$ after home cooking method 2 , while cultivar 1153 - Klainasik presented the highest content of $9-Z$ - $\beta$-carotene isomer after home cooking method 3.

The highest $\mathrm{RR} \%$ in the total carotenoid was found in cultivar 1456 - Vermelhinha $(99.49 \%)$ and in the total $\beta$-carotene (94.31\%) in the cultivar Híbrido 200314 11, both after home cooking process 1 .

Table 3. All- $E, 13$ e 9-Z- $\beta$-carotene isomers contents $(\mu \mathrm{g} / \mathrm{g} \pm \mathrm{SD})$ in raw sweet yellow cassava

\begin{tabular}{|c|c|c|c|}
\hline Cassava roots & $\begin{array}{l}\text { All-E- } \beta \text { - } \\
\text { carotene }\end{array}$ & $\begin{array}{l}\text { I3-Z- } \beta \text { - } \\
\text { carotene }\end{array}$ & $\begin{array}{c}\text { 9-Z- } \beta \text { - } \\
\text { carotene }\end{array}$ \\
\hline Híbrido 20031408 & $7.27 \pm 0.05$ & $0.50 \pm 0.01$ & $0.35 \pm 0.01$ \\
\hline Híbrido 2003 I4 II & $4.23 \pm 0.47$ & $0.37 \pm 0.02$ & $0.76 \pm 0.02$ \\
\hline II 53 - Klainasik & $1.67 \pm 0.01$ & $0.51 \pm 0.01$ & $1.12 \pm 0.05$ \\
\hline I72I - Aipim cacau & $1.58 \pm 0.16$ & $0.47 \pm 0.06$ & $0.79 \pm 0.12$ \\
\hline 1692 - Dendê & $1.71 \pm 0.11$ & $0.42 \pm 0.27$ & $0.25 \pm 0.02$ \\
\hline $\begin{array}{l}\text { I668 - Cacau } \\
\text { amarelo }\end{array}$ & $\mathrm{I} .0 \mathrm{I} \pm 0.0 \mathrm{I}$ & $0.29 \pm 0.01$ & $0.81 \pm 0.01$ \\
\hline I456 - Vermelhinha & $1.00 \pm 0.05$ & $0.52 \pm 0.02$ & $0.47 \pm 0.02$ \\
\hline
\end{tabular}

Each analysis was carried out in triplicate. 


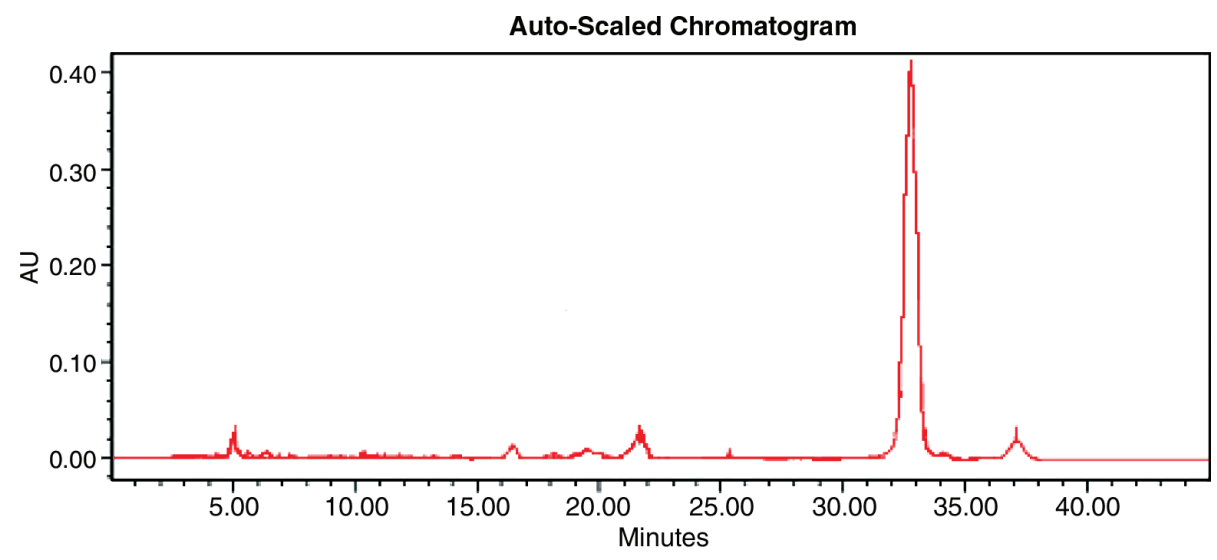

Fig. 3. Chromatogram of the sweet yellow cassava Híbrido 20031408 cultivar.

\section{Discussion}

The correlation coefficient (0.9826) of the calibration curve of the $\beta$-carotene standard and a purity of $90 \%$ were in agreement with Rodriguez-Amaya and Kimura (11) for carrot.

Although the 1456 - Vermelhinha cultivar had the highest total carotenoid content among the seven cultivars, it did not present the highest total $\beta$-carotene $(14 \%)$ content.

The total carotenoid contents in the samples did not present a correlation with those of total $\beta$-carotene. There were no significant differences between the Híbrido 2003 1408 and the Híbrido 20031411 cultivars regarding the total carotenoid and total $\beta$-carotene contents. The all-E- $\beta$-carotene isomer was the most abundant in all the roots.

In another study, the total carotenoid contents were evaluated in 72 yellow and pink cassava, and a mean content of $6.6 \mu \mathrm{g} / \mathrm{g}$ with minimum and maximum values of 0.63 and $15.51 \mu \mathrm{g} / \mathrm{g}$, respectively, were detected in the fresh pulp,. However, out of the 72 cultivars analyzed, only 17 presented total carotenoid contents above $10 \mu \mathrm{g} / \mathrm{g}$ (15). The authors did not discriminate between the evaluated root cultivars (sweet or bitter). These results are similar to those found in the present work.
Normally, the cassava roots cultivars are of poor nutritional quality, having very low carotenoids, iron, zinc, and protein contents in addition to containing toxic cyanogens. The major carotenoid was all- $E$ - $\beta$-carotene. However, unlike sweet potato where the $Z$-isomers are only in trace amounts, cassava roots have appreciable levels of $Z$ - $\beta$-carotene isomers (15).

The total $\beta$-carotene content normally varies from not detected in the white-fleshed roots to approximately $5 \mu \mathrm{g} / \mathrm{g}$ in yellow-fleshed cassava. Seo et al. (16) observed in pumpkins that the $E$ - $\beta$-carotene was the most abundant isomer followed by $\alpha$-carotene.

Studies evaluating the $\beta$-carotene content in fresh cassava roots demonstrated different values varying from 0.2 to $3.0 \mu \mathrm{g} / \mathrm{g}$ (five cultivars), from 3.8 to $4.9 \mu \mathrm{g} / \mathrm{g}$ (three cultivars), and from 0.4 to $3.1 \mu \mathrm{g} / \mathrm{g}$ (10 cultivars) with appreciable amounts of $Z$ - $\beta$-carotene (17-20).

The contents of the 13- and 9-Z- $\beta$-carotene isomers were maintained close to those of the raw roots or presented higher values in the cultivars 1668 - Cacau amarelo, 1692 - Dendê and 1721 - Aipim cacau, Híbrido 20031408 and Híbrido 200314 11, respectively.

It was also observed that the Híbrido $2003 \quad 1408$ cultivar presented a lower percentage of 9 - and $13-Z-\beta$ carotene isomers compared with Híbrido 20031411.

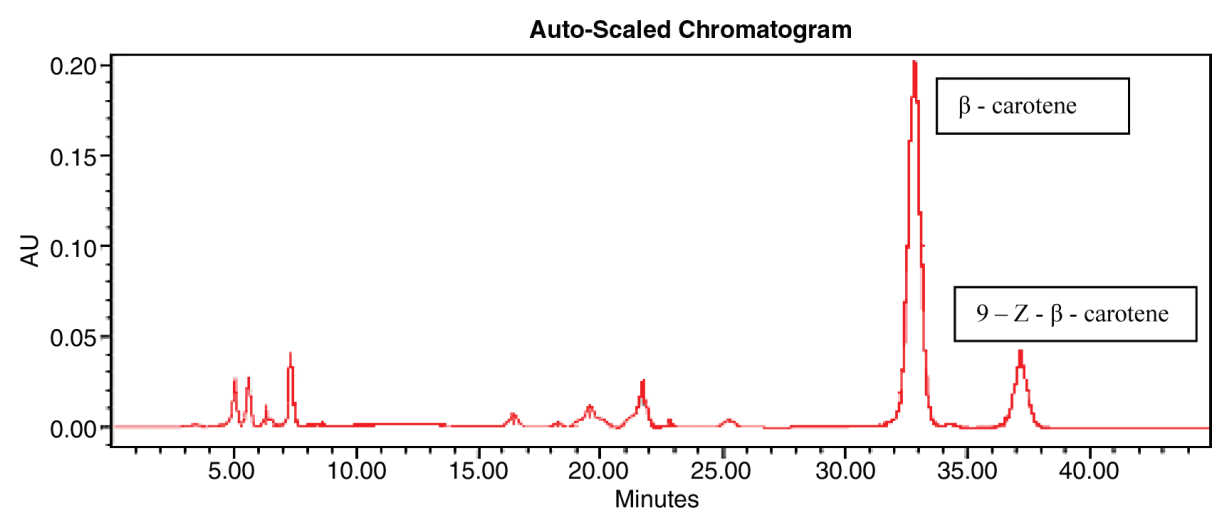

Fig. 4. Chromatogram of the sweet yellow cassava Híbrido 20031411 cultivar. 
Table 4. Total carotenoids, $\beta$-carotene real retention (\%) of yellow sweet yellow cassava roots submitted to three home cooking methods

\begin{tabular}{|c|c|c|}
\hline Cassava roots & Total carotenoids RR (\%) & Total $\beta$-carotene RR (\%) \\
\hline & \multicolumn{2}{|c|}{ I456 - Vermelhinha } \\
\hline I & 99.49 & 33.25 \\
\hline 2 & 92.65 & 33.25 \\
\hline \multirow[t]{2}{*}{3} & 62.97 & 32.06 \\
\hline & \multicolumn{2}{|c|}{ Híbrido 20031408} \\
\hline 1 & 89.2 & 90.84 \\
\hline 2 & 89.2 & 71.25 \\
\hline \multirow[t]{2}{*}{3} & 62.97 & 32.06 \\
\hline & \multicolumn{2}{|c|}{ Híbrido 2003 I4 II } \\
\hline 1 & 77.9 & 94.31 \\
\hline 2 & 73.83 & 76.97 \\
\hline \multirow[t]{2}{*}{3} & 80.9 & 75.76 \\
\hline & \multicolumn{2}{|c|}{ I72I - Aipim cacau } \\
\hline 1 & 65.42 & 65.42 \\
\hline 2 & 69.38 & 69.38 \\
\hline \multirow[t]{2}{*}{3} & 65.23 & 65.23 \\
\hline & \multicolumn{2}{|c|}{ II53-Klainasik } \\
\hline I & 71.86 & 64.39 \\
\hline 2 & 74.45 & 71.99 \\
\hline \multirow[t]{2}{*}{3} & 69.35 & 79.54 \\
\hline & \multicolumn{2}{|c|}{1692 - Dendê } \\
\hline I & 53.61 & 61.86 \\
\hline 2 & 80.96 & 88.07 \\
\hline \multirow[t]{2}{*}{3} & 82.46 & 85.79 \\
\hline & \multicolumn{2}{|c|}{1668 - Cacau amarelo raw } \\
\hline 1 & 68.34 & 72.44 \\
\hline 2 & 77.29 & 73.76 \\
\hline 3 & 66.45 & 67.32 \\
\hline
\end{tabular}

These cultivars resulting from the cross of bitter and sweet yellow cassava were outstanding because of the high $\beta$-carotene content in their roots.

Evaluating the RR\% in sweet yellow cassava roots after home cooking methods demonstrated differences that can be attributed to the contents of the total carotenoids initially found. However, no cooking method provided a higher retention of the total carotenoids or $\beta$-carotene uniformly in all the cultivars, with the behavior of each cultivar of sweet yellow cassava roots prevailing during the cooking process.

A significant difference $(\mathrm{LSD}=46.68, P<0.001)$ was also observed for the average $\mathrm{RR} \%$ of $\beta$-carotene; of the three types of home cooking methods, method 3 preserved the most $(79.80 \pm 20.82)$, followed by methods 2 $(77.54 \pm 17.26)$ and $1(76.99 \pm 21.36)$.

The literature on the $\mathrm{RR} \%$ of total carotenoids and total $\beta$-carotene in sweet yellow cassava roots, as well as on other aspects, is scarce. Therefore, it is difficult to compare the results because the articles reviewed did not always mention the cultivars evaluated. However, Botelho (21) obtained a $59 \% \beta$-carotene retention in the BRS Jari (biofortified) cultivar after being cooked in a pressure pan for $45 \mathrm{~min}$, and $60 \%$ retention was detected in cassava roots cooked in boiling water (20).

The impact on the retention and the $\beta$-carotene bioavailability after the boiling process in gari (roasted cassava granules) and in fufu (fermented and cooked cassava paste) in three Nigeria cassava cultivars were evaluated. The results were similar to those found in the present study in the raw Híbrido 20031408 cultivar $(8.11 \pm 0.06$ of total $\beta$-carotene and $7.27 \pm 0.05$ of all- $E$ - $\beta$-carotene isomer). For the sample cooked in boiling water, a decrease in the all- $E$ - $\beta$-carotene content and an increase in the $13-Z-\beta$-carotene isomers were observed (22).

Studies conducted on yellow sweet potato, cv. Resisto, reported $83-92 \%$ real retention of the total carotenoids after cooking for 20 and $30 \mathrm{~min}$, respectively (23).

In carrots, a $27 \%$ reduction in $\beta$-carotene was reported after cooking under pressure for $10 \mathrm{~min}$ and $16 \%$ when cooking in a covered pot (22).

A reduction in the $\beta$-carotene content of a standard solution at $98^{\circ} \mathrm{C}$ for 60 min was observed by Aman et al. (24), obtaining an RR of $84 \%$. In contrast, Scott and Eldridge (25) did not report a significant $R R$ in carotenoids in fresh and processed corn at $126^{\circ} \mathrm{C}$ for 12 $\min$.

An increase in $\beta$-carotene content from 84.4 (raw) to $100.8 \mu \mathrm{g} / \mathrm{g}(3 \mathrm{~min}$. cooked) and a reduction to $88.6 \mu \mathrm{g} / \mathrm{g}$ after a 5-min bleaching was observed in carrots by Dutta et al. (10).

This result was likely due to the $E-Z$ isomerization caused by the heat applied during the three home cooking methods (24). $E-Z$ isomerization was reported to be caused by heating (27). Ashley and Schwartz (26) evaluated an increase in $Z$-carotenoid isomers, such as lutein and zeaxanthin, in canned broccoli, green peas, and spinach, verifying that the quantitative distribution of the $E$ isomers was lower in the processed samples than in the fresh ones. The $Z$ isomer increase was $11 \%$ in spinach, $6 \%$ in green peas, and $3 \%$ in broccoli. They still concluded that this alteration was due to heating.

The effects of the thermal processes on $\beta$-carotene $E$ - $Z$ isomerization were studied, and small amounts of $Z$ isomers were formed in pasteurized or sterilized carrot juice at $121^{\circ} \mathrm{C}$. However, when submitted to excessive blanching and sterilized at $130^{\circ} \mathrm{C}$, higher $Z$-isomer levels were verified (28).

Lin and Chen (28) evaluated the carotenoid stability in tomato juice after processing and verified increased amounts of $E$-lutein and 9-Z-lutein, attributing it to matrix cell destruction during the heating process of the canned juice in boiling water for $5 \mathrm{~min}$. A similar 
result was also found in juice submitted to sterilization, with an increase of $28 \mu \mathrm{g} / \mathrm{g}$ in $E$-lycopene and $\beta$-carotene.

\section{Conclusions}

The present study revealed differences among the cooking methods regarding total carotenoid or $\beta$-carotene retention. However, no cooking method provided a higher retention of total carotenoids or $\beta$-carotene uniformly in all the cultivars.

Cooking method 1 (complete immersion in water and boiled in a pot without the lid) appeared to be the best regarding $\beta$-carotene retention in Híbrido 20031408 and Híbrido 20031411 cultivars. Unfortunately, it was not possible to indicate the best cooking method for yellow cassava roots. The differences observed may be due to the different behaviors of the cultivars and need further investigation. However, high percentages of total carotenoid or $\beta$-carotene retention were observed and can minimize VAD in low-income populations.

\section{Acknowledgements}

We thank the HarvestPlus program for their full financial support, Embrapa Cassava and Fruits for supplying the cassava samples, and Embrapa Food Technology for allowing us to use their equipment and facilities.

\section{Conflict of interest and funding}

There are no conflicts of interest concerning this study.

\section{References}

1. FAO-Food and agriculture organization of de united nations. Statistical Database - FAOSTAT, http://faostat.fao.org/; 2003 [cited 14 July 2011].

2. Krinsky NI, Johnson EJ. Carotenoid actions and their relation to health and disease. Mol Aspects Med 2005; 26: 459-516.

3. Iglesias C, Mayer J, Chávez AL, Calle F. Genetic potential and stability of carotene content in cassava roots. Euphytica 1997; 94: $367-73$

4. Beyer P, Al-Babilis Y, Lucca P, Schaub P, Welsch R, Potrykus I. Golden rice: introducing the b-carotene biosynthesis pathway into rice endosperm by genetic engineering to defeat vitamin A deficiency. J Nutr 2002; 132: 506S-10S.

5. Ortega-Flores CI, Lopes da Costa MA, Cereda P, Camargo Penteado MV. Bioavailabilty of $\beta$-carotene in dehydrated yellow cassava (Manihot esculenta Crantz). La biodisponibilidad de $\beta$-caroteno en yuca deshidratada hojas (Manihot esculenta Crantz). Ciênc Tecnol Alim 2003; 23(Suppl. 3): 473-7.

6. Wheatley CC. Preservation of cassava roots in polythylene bags. Conservación de raices de yuca en bolsas de polietileno. Cali: Centro Internacional de Agricultura Tropical; 1987, 33p (Serie 045c-07-06).

7. Butarelo SS, Beleia A, Fonseca ICB, Ito KC. Hydration of the cassava roots tissues cassava (Manihot esculenta Crantz.) and starch gelatinization during cooking. Hidratación de los tejidos de las raíces de yuca (Manihot esculenta Crantz.) y gelatinización del almidón durante la cocción. Ciênc Tecnol Alim 2004; 24(Suppl. 3): 311-5.

8. Clydesdale FM, Fleischman DL, Francis FL. Maintenance of color in processed green vegetables. J Food Product 1970; 4: $127-30$.

9. Ihl M, Monslaves M, Bifani V. Chlorophylase inactivation as a measure of blanching efficiency and color retention of artichokes (Cynara scolyus L.). LWT-Food Sci Technol 1998; 31: 56 .

10. Dutta D, Raychaudhuri U, Chahraborty R. Retention of $\beta$-caroteno in frozen carrots under varying conditions of temperature and time of storage. Afr J Biotechnol 2005; 4(Suppl. 1): 103-6.

11. Rodriguez-Amaya DB, Kimura M. HarvestPlus handbook for carotenoid analysis. HarvestPlus technical monograph, 2. Washington, DC and Cali: IFPRI and CIAT; 2004. p. 58.

12. Oliveira ARG, Carvalho LMJ, Nutti RM, Carvalho JLV, Fukuda WG. Assessment and degradation study of total carotenoids and $\beta$-carotene in bitter yellow cassava (Manihot esculenta Crantz) varieties. Afr J Food Sci 2010; 4(Suppl. 4): $148-55$.

13. Davies BH. Carotenoids. In: Goodwing TW, ed. Chemistry and biochemistry of plant pigments, 2nd ed. London: Academic Press; 1976. p. $38-165$.

14. Analytical procedures of the Adolfo Lutz Institute. Procedimientos Analíticos de lo Instituto Adolfo Lutz. 3rd ed. São Paulo, Brazil: Adolfo Lutz Institute; 1985.

15. Kimura M, Kobori CN, Rodriguez-Amaya DB, Nestel $P$. Screening and HPLC methods for carotenoids in sweetpotato, cassava and maize for plant breeding trials. Food Chem 2007; 100: $1734-46$.

16. Seo JS, Burri BJ, Quan Z, Neidlinger TR. Extraction and chromatography of carotenoids from pumpkin. J Chromat A 2005; 1073: 371-5.

17. Adewusi SRA, Bradbury JH. Carotenoids in cassava: comparison of open-column and HPLC methods of analysis. J Sci Food Agric 1993; 62: 375-83.

18. Chávez AL, Sánchez T, Ceballos H, Rodriguez-Amaya D, Nestel P, Tohme J, et al. Retention of carotenes in cassava roots upon e processing methods. J Sci Food Agric 2007; 87: 388-93.

19. Moorthy SN, Jos JS, Nair RB, Sreekumari MT. Variability of $\beta$-carotene in cassava germplasm. Food Chem 1990; 36: $233-6$.

20. Van Jaarsveld PJV, Marais DW, Nestel P, Rodriguez-Amaya DB. Retention of $\beta$-carotene in boiled, mashed orangefleshed sweet potato. J Food Comp Anal 2006; 4(Suppl. 19): 321-9.

21. Botelho SG. Evaluation of the $\beta$-carotene bioacessability in raw yellow cassava roots (Manihot esculenta Crantz) and the cooking and frying effects. Rio de Janeiro, Brazil: Tesis Rio de Janeiro federal University; 2011.

22. Gayathri GN, Platel K, Prakash J, Srinivasan K. Influence of antioxidant spices on the retention of $\beta$-carotene in vegetables during domestic cooking processes. Food Chem 2004; 84: $35-43$.

23. Van Jaarsveld PJV, Marais DW, Nestel P, Rodriguez-Amaya DB. Retention of $\beta$-carotene in boiled, mashed orangefleshed sweet potato. J Food Comp Anal 2006; 4(Suppl. 19): $321-9$.

24. Aman R, Schieber A, Carle R. Effects of heating and illumination on trans-cis isomerization of beta-carotene and lutein in isolated spinach chloroplasts. J Agric Food Chem 2005; 53: $9512-8$. 
25. Scott CE, Eldridge AL. Comparison of carotenoids content in fresh, frozen and canned corn. J Food Comp Anal 2005; 18: 551-9.

26. Ashley A, Schwartz SJ. Thermal processing of vegetables increase cis isomers of lutein and zeaxantina. J Agric Food Chem 2003; 51: 6184-90.

27. Schieber A, Carle R. Occurrence of carotenoid cis-isomers in food: technological, analytical and nutritional implications. Trends Food Sci Technol 2005; 16: 416-22.

28. Lin $\mathrm{CH}$, Chen BH. Stability of carotenoids in tomato juice during processing. Eur Food Res Tecnhol 2005; 221: 274-80.
*Lucia M. J. Carvalho

Pharmacy College

Rio de Janeiro Federal University

Av. Carlos Chagas Filho

373, CCS, bl. L, Lab. 17.

Rio de Janeiro 21941.590

Brazil

Tel: +55 21 22609192 or 22801784 ext. 250/ +55 21 25721।63

Email: luciajaeger@gmail.com 